\title{
Dextran sulfate sodium and 2,4,6-trinitrobenzene sulfonic acid induce lipid peroxidation by the proliferation of intestinal gram-negative bacteria in mice
}

In-Ah Lee, Eun-Ah Bae, Yang-Jin Hyun, Dong-Hyun Kim*

\begin{abstract}
Abstrect
Background: To understand whether TLR-4-linked NF-kB activation negatively correlates with lipid peroxidation in colitic animal models, we caused colitis by the treatment with dextran sulfate sodium (DSS) or 2,4,6-

trinitrobenzenesulfonic acid (TNBS) to $\mathrm{C} 3 \mathrm{H} / \mathrm{HeJ}$ (TLR-4-defective) and $\mathrm{C} 3 \mathrm{H} / \mathrm{HeN}$ (wild type) mice, investigated inflammatory markers, lipid peroxidation, proinflammatory cytokines and TLR-4-linked NF- $\kappa B$ activation, in colon and intestinal bacterial composition in vivo.

Methods: Orally administered DSS and intrarectally injected TNBS all caused severe inflammation, manifested by shortened colons in both mice. These agents increased intestinal myeloperoxidase activity and the expression of the proinflammatory cytokines, IL-1 $\beta$, TNF- $\alpha$ and IL-6, in the colon.

Results: DSS and TNBS induced the protein expression of TLR-4 and activated transcription factor NF- $\kappa$ B. However, these colitic agents did not express TLR-4 in $\mathrm{C} 3 \mathrm{H} / \mathrm{HeJ}$ mice. Of proinflammatory cytokines, IL-1 $\beta$ was most potently expressed in $\mathrm{C} 3 \mathrm{H} / \mathrm{HeN}$ mice. IL-1 $\beta$ potently induced NF- $\kappa \mathrm{B}$ activation in CaCo-2 cells, but did not induce TLR-4 expression. DSS and TNBS increased lipid peroxide (malondialdehyde) and 4-hydroxy-2-nonenal content in the colon, but reduced glutathione content and superoxide dismutase and catalase activities. These colitic inducers increased the number of Enterobacteriaceae grown in DHL agar plates in both mice, although the number of anaerobes and bifidobacteria grown in GAM and BL agar plates was reduced. E. coli, K. pneumoniae and Proteus mirabilis isolated in DHL agar plates increased lipid peroxidation in liposomes prepared by L- $\alpha$-phosphatidylcholine, but $B$. animalis and B. cholerium isolated from $B L$ agar plates inhibited it.

Discussion: These findings suggest that DSS and TNBS may cause colitis by inducing lipid peroxidation and enterobacterial proliferation, which may deteriorate the colitis by regulating proinflammatory cytokines via TLR-4linked NF- $\kappa$ B activation pathway.
\end{abstract}

\section{Background}

Inflammatory bowel disease (IBD), including ulcerative colitis and Crohn disease, are chronically relapsing disorders of the intestine [1,2]. Its pathogenic mechanism is assumed to be a dysregulation of the intestinal immune response to intestinal environmental antigens, such as intestinal microflora, and characterized by the activation of lymphocytes, macrophages, enterocytes and

\footnotetext{
* Correspondence: dhkim@khu.ac.kr

Department of Life and Nanopharmaceutical Sciences, Kyung Hee University, 1, Hoegi, Dongdaemun-Ku, Seoul 130-701, Korea
}

endothelial cells, which cause the production of inflammatory mediators, such as IL- $1 \beta$, IL- 6 and TNF- $\alpha[3,4]$. Intestinal microflora may play an important role in initiating and perpetuating colonic inflammation. Intestinal bacterial endotoxins, such as lipopolysaccharides (LPS), penetrate the epithelial barrier, either due to damage or via paracellular pathways, in order to directly stimulate the mucosal immune system [5]. Alternatively, it is also possible that enteric endotoxins may interact at the apical surface and induce responses in the intestinal epithelial cells. These may result in the production of
C Biomed Central

(c) 2010 Lee et al; licensee BioMed Central Ltd. This is an Open Access article distributed under the terms of the Creative Commons Attribution License (http://creativecommons.org/licenses/by/2.0), which permits unrestricted use, distribution, and reproduction in any medium, provided the original work is properly cited. 
proinflammatory cytokines, such as TNF- $\alpha$ and IL- $1 \beta$, and other mediators, such as myeloperoxidase and reactive oxygen species (ROS), causing the inflammatory activation of the mucosal immune system via distinct signaling pathways through Toll-like receptors (TLRs) and/or cytokine receptors [6].

TLRs, which serve as a major link between the innate and adaptive mucosal immune responses, act as transmembrane co-receptors with CD14 in the cellular response to LPS [7]. Among this family of receptors, TLR-4, which is linked in the activation of transcription factor NF- $\kappa \mathrm{B}$, may potentially serve as the main mediators of LPS signaling in the IBD [8]. The activation of $\mathrm{NF}-\kappa \mathrm{B}$ in mucosal macrophages is accompanied by an increased capacity of these cells to produce and secrete IL-1, IL- 6 and TNF- $\alpha$. These cytokines stimulate NF-kB activation. IBD was not developed or progressed in germfree IL-10-deficient or IL-2 receptor-deficient animals as well as in TLR-4 knockout animals, by colitic inducers, dextran sulfate sodium (DSS) and 2,4,6-trinitrobenzene sulfonic acid (TNBS) [9-11]. Therefore, the analysis of TLR-linked NF- $\kappa$ B activation, proinflammatory cytokine expression patterns and intestinal gram-negative bacterial quantity in IBD experimental animals could serve as a helpful tool to characterize intestinal inflammation.

Reactive oxygen species (ROS), such as peroxide anion, hydrogen peroxide, and hypochlorous acid, may be involved in the pathogenesis of IBD. The colitic inducers, DSS and TNBS, increase malondialdehyde and 4hydroxy-2-nonenal (4-HNE) in the colons of both mice, but reduced the glutathione content and superoxide dismutase and catalase activities, as previously reported [12-14]. Treatment with superoxide dismutase significantly ameliorates colitis [15].

In the present study, we conducted experimental colitis by DSS or TNBS in $\mathrm{C} 3 \mathrm{H} / \mathrm{HeN}$ and $\mathrm{C} 3 \mathrm{H} / \mathrm{HeJ}$ mice and investigated the relationship between colonic inflammatory markers, such proinflammatory cytokines and lipid peroxidation activation, in colon and colonic gram-negative bacterial quantity.

\section{Method}

\section{Materials}

Dulbecco's modified Eagle medium (DMEM), tetramethyl benzidine, Griess reagent, DSS, hexadecyl trimethyl ammonium bromide, and radio-immunoprecipitation assay (RIPA) lysis buffer were purchased from Sigma Co. (St Louis, MO, USA). A protease inhibitor cocktail was from Roche Applied Science (Mannheim, Germany). ELISA Kits were obtained from Pierce Biotechnology, Inc., (Rockford, IL, USA). Antibodies for of pp65 (phospho-NF- $\kappa \mathrm{B}$ ), p65 (NF- $\kappa \mathrm{B})$, and $\beta$-actin were purchased from Santa Cruz Biotechnology (Santa Cruz, CA, U.S.A.) and Cell signaling technology Inc. (Danvers, MS, U.S.A.), respectively. Enhanced chemiluminescence (ECL) immunoblot system was obtained from Pierce Co. (Rockford, IL, U.S.A.). 4-HNE was purchased from Cayman Chemical Co. (Ann Arbor, MI, U.S.A.).

\section{Culture of CaCo-2 cells}

The human colon cancer cell line Caco-2 (KCLB 30037, Korean Cell Line Bank, Seoul, Korea) was cultured in DMEM supplemented with $10 \%$ heat-inactivated FBS, 2 $\mathrm{mM}$ L-glutamine, $1 \%$ nonessential amino acids, and antibiotics. SW-480 were cultured in Eagle's MEM supplemented with $10 \% \mathrm{FBS}, 2 \mathrm{mM} \mathrm{L}$-glutamine, and antibiotics [16]. Cells were cultured in a water-saturated atmosphere of $95 \%$ air and 5\% CO. For immunoblot analysis of NF- $\kappa$ B , TLR- 4 and $\beta$-actin, $5 \times 10^{5}$ cells were seeded into a six-well tissue culture plate $(2 \mathrm{ml} /$ well) and were incubated at 50 to $70 \%$ confluency (normally 1 to 2 days after seeding). The medium was then removed, and the cells were incubated at various times with or without IL-1 $\beta$. Viability before and after plating was $>95 \%$ by trypan blue dye exclusion.

\section{Liposome preparation and lipid peroxidation-inhibitory activity assay}

For the liposome preparation, $\mathrm{L}-\alpha$-phosphatidylcholine (0.1 g, type XV-E from egg yolk) was dissolved in diethyl ether $(10 \mathrm{ml})$ and distilled water $(0.6 \mathrm{ml})$ was added. The mixture was sonicated with an ultrasonic disrupter (Eyelar Co., Tokyo, Japan) and evaporated under vacuum on ice. The resulting extract was suspended in $30 \mathrm{ml}$ of $0.1 \mathrm{M} \mathrm{N}$-(2-acetamido)-imidinodiacetic acid (ADA) sodium buffer ( $\mathrm{pH}$ 6.7), sonicated for $15 \mathrm{~min}$ on ice, and centrifuged at $1,500 \times \mathrm{g}$ for $\min$ at $4^{\circ} \mathrm{C}$. The supernatant was used as the liposome suspension.

To assay the lipid peroxidation-inhibitory activity, the liposomal suspension $(0.1 \mathrm{ml})$ was incubated in $1.5 \mathrm{ml}$ of $50 \mathrm{mM}$ sodium phosphate buffer (pH 6.7), $0.1 \mathrm{ml}$ of $2 \mathrm{mM}$ ferrous chloride, and $0.1 \mathrm{ml}$ of $4 \mathrm{mM}$ sodium ascorbate for $2 \mathrm{~h}$ at $37^{\circ} \mathrm{C}$ in the presence or absence of bacterial cells. Lipid peroxide in the reaction mixture was quantified as thiobarbituric acid-reactive substances (TBARS) as reported previously [17].

\section{Animals}

Male $\mathrm{C} 3 \mathrm{H} / \mathrm{HeN}$ and $\mathrm{C} 3 \mathrm{H} / \mathrm{HeJ}$ mice $(24-28 \mathrm{~g})$ were supplied by Orient Experimental Animal Breeding Center (Seoul, Korea). C3H/HeJ mice possess a missense mutation in the TLR-4 gene, which leads to a single amino acid change in the cytoplasmic portion of TLR-4, impeding signal transduction and leading to a phenotype similar to that of TLR-4 knockout mice [18]. C3H/HeJ mice are defective in TLR-4 signaling and in responding to LPS [TLR-4 $4^{(\text {LPS-d })}$. All animals were housed in wire cages at $20-22^{\circ} \mathrm{C}$ and $50 \pm 10 \%$ humidity, fed standard 
laboratory chow (Samyang, Seoul, Korea) and allowed water ad libitum. All procedures relating to animals and their care conformed to the international guidelines 'Principles of Laboratory Animals Care' (NIH publication no. 85-23 revised 1985 and Kyung Hee University 2006).

\section{Preparation of experimental colitis}

The colitic mice induced by DSS and TNBS were prepared according to the methods of Dieleman et al. [19] and Neurath et al. [20], respectively.

TNBS-and DSS-induced colitis in $\mathrm{C} 3 \mathrm{H} / \mathrm{HeN}$ and TLR4 knockout $\mathrm{C} 3 \mathrm{H} / \mathrm{HeJ}$ mice was prepared according to the above protocols. These mice were anesthetized with ether and then sacrificed on the $3^{\text {rd }}$ and $7^{\text {th }}$ day after the administration of TNBS and DSS, respectively.

Physical appearance, consistency of feces, diarrhea, the presence of gross blood in stool, and body weight were monitored daily. Macroscopic assessment of the disease grade was scored according to a previously reported scoring system ( 0 , no ulcer and no inflammation; 1 , ulceration and local hyperemia; 2, ulceration without hyperemia; 3, ulceration and inflammation at one site only; 4, two or more sites of ulceration and inflammation; 5, ulceration extending more than $2 \mathrm{~cm}$ [21], and the colon tissue was then used for immunoblot and enzyme-linked immunosorbent assay (ELISA) analysis.

For histopathological examination, a segment of colon tissues was flash frozen in lipid nitrogen and kept at $-80^{\circ} \mathrm{C}$ for further analysis and another portion was fixed in formalin. Formalin sections were stained with hematoxylin-eosin and evaluated by light microscopy for the presence of lesions.

\section{Assay of myeloperoxidase activity in colonic mucosa}

The colons isolated from the mice were homogenized in a solution containing $0.5 \%$ hexadecyl trimethyl ammonium bromide dissolved in $10 \mathrm{mM}$ potassium phosphate buffer ( $\mathrm{pH} 7.0)$, and then centrifuged for $30 \mathrm{~min}$ at $20,000 \times \mathrm{g}\left(4^{\circ} \mathrm{C}\right)$. An aliquot $(50 \mu \mathrm{l})$ of the supernatant was added to a reaction mixture consisting of $1.6 \mathrm{mM}$ tetramethyl benzidine and $0.1 \mathrm{mM} \mathrm{H}_{2} \mathrm{O}_{2}$, incubated at $37^{\circ} \mathrm{C}$ and then the absorbance obtained at $650 \mathrm{~nm}$ spectophotometrically time-scanned. The myeloperoxidase activity was defined as the quantity of enzyme degrading $1 \mu \mathrm{mol} / \mathrm{ml}$ of peroxide at $37^{\circ} \mathrm{C}$, and expressed in unit/ $\mathrm{mg}$ protein [22]. The protein content was assayed by Bradford's method [23].

\section{Assay of lipid peroxide (malondialdehyde), reduced glutathione amount and superoxide dismutase and catalase activities}

Lipid peroxidation was estimated in colon homogenates as described by Ohkawa et al. [24]. Briefly, a reaction mixture containing $50 \mathrm{mM}$ Tris- $\mathrm{HCl}$ buffer (pH 7.4), 500 $\mu \mathrm{M}$ tert-butyl hydroperoxide (BHP) (in ethanol) and 1 $\mathrm{mM}$ ferrous chloride was incubated with the samples at $37^{\circ} \mathrm{C}$ for $90 \mathrm{~min}$. The reaction was terminated by adding $0.2 \mathrm{ml}$ of $8 \%$ sodium dodecyl sulfate followed by $1.5 \mathrm{ml}$ of $20 \%$ acetic acid (pH 3.5). The amount of malondialdehyde formed during the incubation was assessed by adding $1.5 \%$ thiobarbituric acid and then heating at $95^{\circ} \mathrm{C}$ for $45 \mathrm{~min}$. After cooling, the samples were centrifuged, and the absorbance of TBARS in the supernatant was measured at $532 \mathrm{~nm}$. The levels of lipid peroxidation are expressed in terms of nmol TBARS/90 $\mathrm{min} / \mathrm{mg}$ protein.

The amount of reduced glutathione in the tissue homogenate was estimated according to the method of Paglia and Valentine [25]. Catalase and superoxide dismutase activities were estimated according to the method of Prakash et al. [26].

\section{Analysis of HNE by HPLC}

The colon ( $1 \mathrm{~g}$ ) was suspended in $1 \mathrm{ml}$ of lysis buffer, homogenized, centrifuged at $13000 \mathrm{rpm}$ for $20 \mathrm{~min}$ twice, and the supernatant was analyzed for 4-HNE using HPLC (Younglin high performance liquid chromatography system): column, Develosil ODS-UG-5 (4.6 mm i.d. $\times 150$ $\mathrm{mm}, 5.8 \mu \mathrm{m}$ particle diameter); mobile phase, linear-gradient mixture of $10 \%$ acetonitrile and $90 \%$ acetonitrile for 0 - $20 \mathrm{~min}$ and 100\% acetonitrile for 20 - $30 \mathrm{~min}$; flow rate, $1 \mathrm{ml} / \mathrm{min}$; and detection, $\mathrm{UV}$ at $230 / 233 \mathrm{~nm}$.

\section{Enzyme-linked immunosorbent assay (ELISA) and immunoblot}

For the ELISA of IL- $1 \beta$ and IL- 6 , colons were homogenized in $1 \mathrm{ml}$ ice-cold lysis buffer (Radio-immunoprecipitation assay, RIPA) containing $1 \%$ a protease inhibitor cocktail and $1 \%$ phosphatase inhibitor cocktail). The lysate was centrifuged $(15,000 \times \mathrm{g}, 4 \mathrm{C})$ for $15 \mathrm{~min}$, and the supernatant transferred to 96 -well ELISA plates. IL- $1 \beta$ and IL-6 concentrations were determined using commercial ELISA kits (Pierce Biotechnology, Inc., Rockford, IL, USA).

For the immunoblot of pp65 (phospho-NF- $\kappa \mathrm{B}$ ), p65 $(\mathrm{NF}-\kappa \mathrm{B}), \mathrm{COX}-2$, iNOS, TLR- 4 and $\beta$-actin, the colon tissue was carefully homogenized to obtain many viable single cells, which were resuspended in $1 \mathrm{ml}$ of RIPA lysis buffer containing $1 \%$ a protease inhibitor cocktail and $1 \%$ phosphatase inhibitor cocktail). After centrifugation, the supernatant was used for the immunoblot assay. The total protein from the collected cells was subjected to electrophoresis on an $8-10 \%$ sodium dodecyl sulfate-polyacrylamide gel, and then transferred to a nitrocellulose membrane. The expression levels of pp65 (phospho-NF- $\kappa \mathrm{B}$ ), p65 (NF- $\kappa \mathrm{B}$ ), COX-2, iNOS, TLR-4 and $\beta$-actin were assayed using their corresponding antibodies, according to a previously reported method [27]. Immunodetection was carried out using an enhanced chemiluminescence detection kit. 


\section{Fecal bacterial suspension preparation and enzyme} activity assay

Fresh mouse stools $(0.5 \mathrm{~g})$ from each group were collected separately in sterilized plastic cups, carefully suspended in 20-volumes of saline in a cooled tube and centrifuged at $250 \times \mathrm{g}$ for $5 \mathrm{~min}$. The supernatant was then centrifuged at $10,000 \times \mathrm{g}$ for $20 \mathrm{~min}$. The resulting precipitates were used as the sources for the fecal enzyme assays. All procedures were performed at $4^{\circ} \mathrm{C}$.
Bacterial enzyme activity assays for $\beta$-glucuronidase and hyaluronic acid degradation were performed according to the method of Lee et al. [28].

\section{Bacterial culture in mouse stools and their identification}

Fresh mouse stools ( $0.5 \mathrm{~g}$ ) from each group were collected separately in sterilized plastic cups, carefully suspended in 20-volumes of peptone water, diluted 10-fold in a stepwise manner, and inoculated in agar plates of
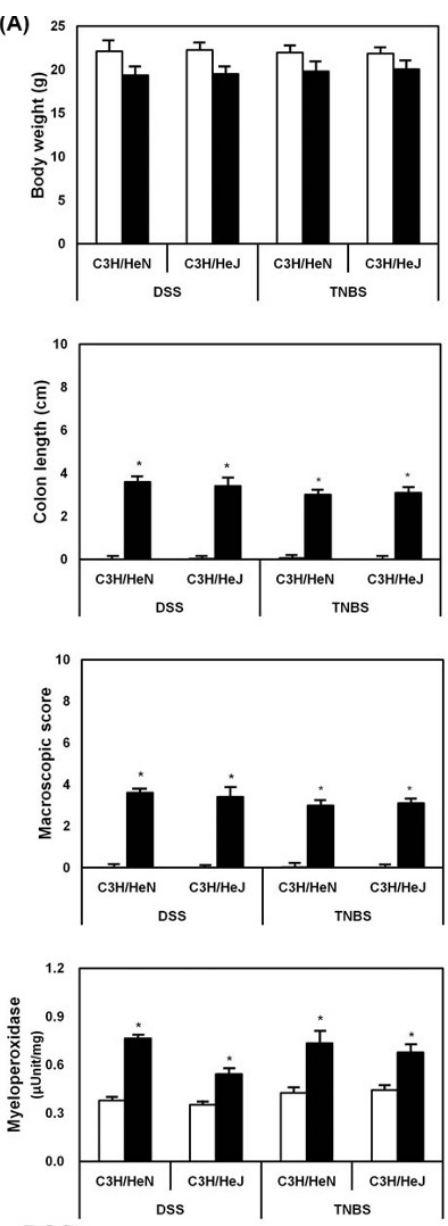

(B) DSS
$\mathrm{C} 3 \mathrm{H} / \mathrm{HeJ}$
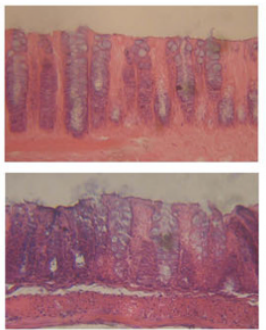

TNBS

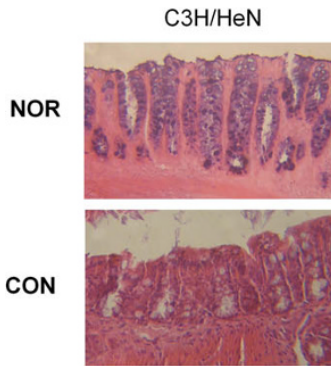

$\mathrm{C} 3 \mathrm{H} / \mathrm{HeN}$
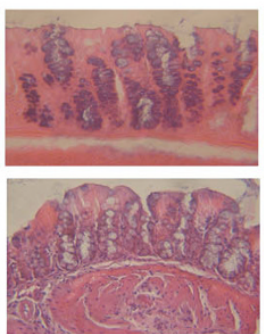

$\mathrm{C} 3 \mathrm{H} / \mathrm{HeJ}$

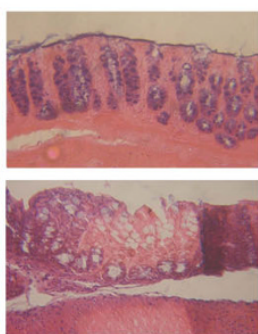

Figure 1 DSS or TNBS affects body weight (A), colon length (B), macroscopic score (C) and intestinal myeloperoxidase activity (D) in $\mathrm{C} 3 \mathrm{H} / \mathrm{HeN}$ and $\mathrm{C} 3 \mathrm{H} / \mathrm{HeJ}$ mice. A histopathological exam was performed by hematoxylin-eosin staining (E). The mice treated with DSS or TNBS were sacrificed on the $7^{\text {th }}$ and $3^{\text {rd }}$ day, respectively: the white bar, normal group; and black bar, DSS or TNBS-treated group. The values of enzyme activities indicate the mean \pm S.D. $(n=7)$. * Significantly different compared with normal group $(p<0.05)$. 
blood liver medium (BL, Nissui Pharm. Co., Ltd), general anaerobic medium (BL GAM, Nissui Pharm. Co. Ltd) and hydrogen sulfate lactose medium (DHL, Eiken Chem. Co., Ltd). DHL agar plates were cultured anaerobically for 1 day at $37^{\circ} \mathrm{C}$, and $\mathrm{BL}$ and GAM agar plates were cultured aerobically for 3 days at $37^{\circ} \mathrm{C}$.

The colonies grown in DHL agar media were identified by $16 \mathrm{~S}$ rDNA gene sequencing [29]. Total DNA extracted from the colonies was used as a template to amplify the $16 \mathrm{~S}$ rRNA gene with primers $27 \mathrm{f}\left(5^{\prime}\right.$ AGAGTTTGATCCTGGCTCAG-3') and 1525r (5'AAAGGAGGTGATCCAGCC-3'), and its sequence was analyzed using BLAST search.

\section{Bacterial strains and growth conditions}

Five intestinal bacterial strains were used in this study: Bifidobacterium animalis (B1) and Bifidobacterium cholerium (B2) isolated from BL agar plates and Escherichi coli (Ec), Klebsiella pneumoniae (Kp) and Proteus mirabilis (Pm) isolated for DHL agar plates.

Each bacterial strain was grown to an optical density between 3 and 4 at $600 \mathrm{~nm}$ in GAM broth, collected by centrifugation $(10,000 \times \mathrm{g}$ for $30 \mathrm{~min})$ and washed twice with saline. The resulting pellet was used for lipid peroxidation-inhibitory activity assay.

\section{Statistical analysis}

All data are expressed as the mean \pm standard deviation, with statistical significance analyzed using one-way ANOVA followed by a Student-Newman-Keuls test.

\section{Results}

To evaluate the relationship between TLR-4-linked inflammatory reaction and intestinal gram-negative bacteria, colitis was induced by the oral administration of DSS for 7 days and intrarectal injection of TNBS in $\mathrm{C} 3 \mathrm{H} /$
$\mathrm{HeN}$ and $\mathrm{C} 3 \mathrm{H} / \mathrm{HeJ}$ mice, and colitic markers were measured. All normal animals showed body weight gain, but DSS and TNBS treatment reduced body weight gain. These colitic inducers, DSS and TNBS, caused severe inflammation, manifested by shortened, thickened, and erythematous colons in both mice. In macroscopic histology, these inducers showed massive bowel edema and epithelial cell disruption by large ulcerations in both mice (Fig. 1). Myeloperoxidase, an inflammatory marker, was also potently increased in both mice. The colitic inducers also induced lipid peroxide (malondialdehyde) and 4-HNE levels in the colons of $\mathrm{C} 3 \mathrm{H} / \mathrm{HeN}$ and $\mathrm{C} 3 \mathrm{H} /$ $\mathrm{HeJ}$ mice, but reduced the glutathione content and superoxide dismutase and catalase activities (Table 1).

Treatment with DSS or TNBS also increased levels of the pro-inflammatory cytokines, IL- 6 and TNF- $\alpha$, in the colon of both mice (Fig. 2). IL-1 $\beta$ was significantly increased in $\mathrm{C} 3 \mathrm{H} / \mathrm{HeN}$ mice, but not in $\mathrm{C} 3 \mathrm{H} / \mathrm{HeJ}$ mice. The treatment with these colitic inducers potently induced TLR-4 expression in $\mathrm{C} 3 \mathrm{H} / \mathrm{HeN}$ mice, and activated $\mathrm{NF}-\kappa \mathrm{B}$. However, the treatment with DSS and TNBS in $\mathrm{C} 3 \mathrm{H} / \mathrm{HeJ}$ did not express TLR-4, although NF$\kappa \mathrm{B}$ was activated. IL-1 $\beta$ potently induced NF-kB in CaCo- 2 cells, but did not increase TLR-4 expression (Fig 3).

When $\mathrm{C} 3 \mathrm{H} / \mathrm{HeN}$ and $\mathrm{C} 3 \mathrm{H} / \mathrm{HeJ}$ mice were treated with DSS or TNBS, the number of anaerobes grown in GAM agar plate and bifidobacteria in BL agar plate was significantly reduced, but the number of colonies grown in DHL medium, which is a selective medium for Enterobacteriaceae, was significantly increased (Table 2). Proteus mirabilis, E. coli, and $K$. pneumoniae were mainly detected in $\mathrm{C} 3 \mathrm{H} / \mathrm{HeN}$ mice. However, $P$. mirabilis was detected in $\mathrm{C} 3 \mathrm{H} / \mathrm{HeJ}$ mice, although $E$. coli, and $K$. pneumoniae were detected. Among intestinal bacteria grown in BL and DHL agar plates, bifidobacteria grown,

Table 1 Effect of colitic inducers, TNBS and DSS, on lipid peroxide (malondialdehyde, MDA), 4-hydroxy-2-nonenal (4HNE), and glutathione (GSH) contents and superoxide dismutase (SOD), and catalase activities in the colons of $\mathrm{C} 3 \mathrm{H} /$ $\mathrm{HeN}$ and $\mathrm{C} 3 \mathrm{H} / \mathrm{HeJ}$ mice

\begin{tabular}{|c|c|c|c|c|c|c|}
\hline & \multirow[t]{2}{*}{ Colitic inducer } & \multicolumn{3}{|c|}{ Content } & \multicolumn{2}{|c|}{ Activity } \\
\hline & & MDA $(\mu \mathrm{M} / \mathrm{mg})$ & 4-HNE (ng/ml) & $\mathrm{GSH}(\mu \mathrm{g} / \mathrm{ml})$ & SOD (Unit/mg) & Catalase $(\mathrm{mol} / \mathrm{min} / \mathrm{mg})$ \\
\hline \multirow[t]{2}{*}{$\mathrm{C} 3 \mathrm{H} / \mathrm{HeN}$} & $-a^{a}$ & $0.74 \pm 0.51$ & $0.86 \pm 0.85$ & $1.51 \pm 1.14$ & $3.76 \pm 1.30$ & $5.22 \pm 1.33$ \\
\hline & DSS & $5.60 \pm 1.04^{\#}$ & $11.92 \pm 7.01^{\#}$ & $4.53 \pm 0.15^{\#}$ & $1.06 \pm 0.13^{\#}$ & $0.19 \pm 0.94^{\#}$ \\
\hline \multirow[t]{2}{*}{$\mathrm{C} 3 \mathrm{H} / \mathrm{HeJ}$} & $-^{a}$ & $0.72 \pm 0.56$ & $2.52 \pm 3.11$ & $0.67 \pm 0.38$ & $5.21 \pm 1.83$ & $6.25 \pm 1.21$ \\
\hline & DSS & $5.39 \pm 1.00^{\#}$ & $2.93 \pm 2.26^{\#}$ & $4.57 \pm 0.12^{\#}$ & $0.72 \pm 0.17^{\#}$ & $0.60 \pm 1.41^{\#}$ \\
\hline \multirow[t]{2}{*}{$\mathrm{C} 3 \mathrm{H} / \mathrm{HeN}$} & $\AA^{a}$ & $0.99 \pm 0.09$ & $3.31 \pm 0.15$ & $4.92 \pm 1.33$ & $3.39 \pm 0.34$ & $7.53 \pm 0.77$ \\
\hline & TNBS & $5.11 \pm 0.67^{\#}$ & $15.92 \pm 4.03^{\#}$ & $2.19 \pm 0.24^{\#}$ & $0.16 \pm 0.04^{\#}$ & $1.49 \pm 1.00^{\#}$ \\
\hline \multirow[t]{2}{*}{$\mathrm{C} 3 \mathrm{H} / \mathrm{HeJ}$} & $\mathrm{a}^{\mathrm{a}}$ & $0.66 \pm 0.06$ & $1.53 \pm 1.80$ & $4.38 \pm 0.93$ & $3.64 \pm 0.47$ & $4.76 \pm 0.65$ \\
\hline & TNBS & $2.95 \pm 0.94^{\#}$ & $3.57 \pm 0.89^{\#}$ & $2.13 \pm 0.25^{\#}$ & $0.50 \pm 0.03^{\#}$ & $0.82 \pm 0.65^{\#}$ \\
\hline
\end{tabular}

The test agents were orally administered once every day for 3 days prior to TNBS treatment. The mice were anesthetized with ether and killed 3 days after TNBS treatment.

a) Normal group treated with vehicle alone instead of colitic inducer.

All values are the mean \pm S.D. $(n=10)$. " Significantly different vs normal group in each column of $C 3 \mathrm{H} / \mathrm{HeN}$ or $C 3 \mathrm{H} / \mathrm{HeJ}$ mice $(P<0.05)$. 

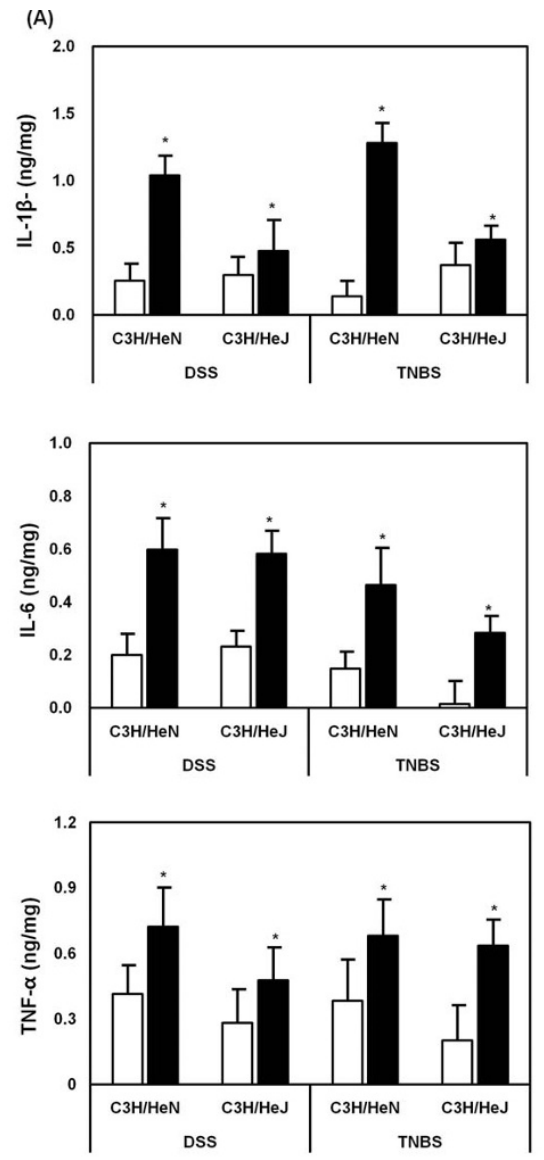

(B)
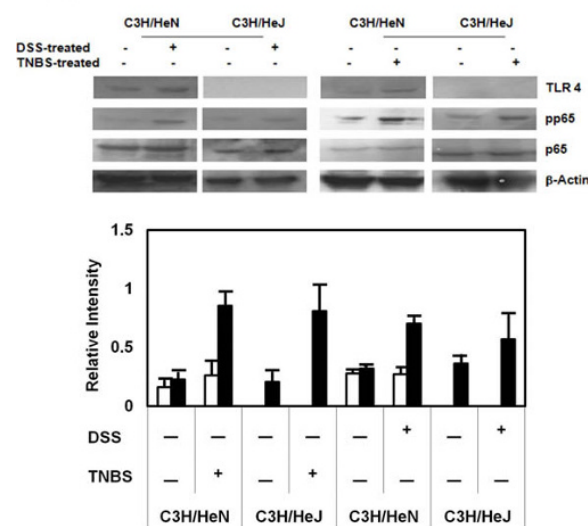

Figure 2 DSS or TNBS induces proinflammatory cytokine expression and activates transcription factor NF- $\kappa \mathrm{B}$ in $\mathrm{C} 3 \mathrm{H} /$ $\mathrm{HeN}$ and $\mathrm{C} 3 \mathrm{H} / \mathrm{HeJ}$ mice. (A) Colitic inducers increased the protein expression of IL-1 $\beta, I L-6$ and TNF- $\alpha$ in the colon of mice. The mice treated with DSS or TNBS were sacrificed on the $7^{\text {th }}$ and $3^{\text {rd }}$ day, respectively: the white bar, normal group; and black bar, DSS or TNBS-treated group. These cytokines were determined by ELISA assays. The values of enzyme activities indicate the mean \pm S.D. (n $=7)$. ${ }^{*}$ Significantly different in each cytokine of DSS or TNBStreated mice compared with normal group $(p<0.05)$. (B) Colitic inducer increased TLR- 4 expression (white bar) and activated NF- $\kappa$ B (black bar). These expressions were measured by immunoblot analysis.

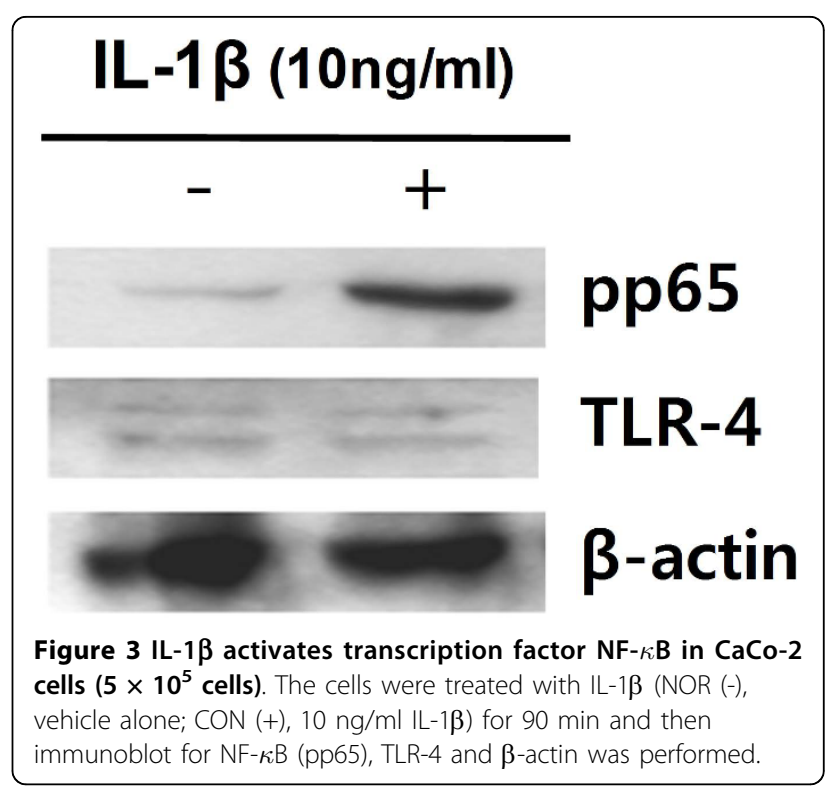

Table 2 Effect of colitic inducers, TNBS and DSS, on number of anaerobes and Enterobacteriaceae in $\mathrm{C} 3 \mathrm{H} /$ $\mathrm{HeN}$ and $\mathrm{C} 3 \mathrm{H} / \mathrm{HeJ}$ mice

\begin{tabular}{|c|c|c|c|c|c|c|}
\hline \multirow[t]{3}{*}{ Mouse } & \multirow{3}{*}{$\begin{array}{l}\text { Colitic } \\
\text { inducer }\end{array}$} & \multicolumn{5}{|c|}{ Number of colonies grown in agar plate } \\
\hline & & \multirow{2}{*}{$\begin{array}{l}\text { GAM } \\
\text { (Anaerobes) } \\
\left(\times 10^{10}\right)\end{array}$} & \multirow{2}{*}{$\begin{array}{l}\text { BL } \\
\text { (Bifido) } \\
\left(\times 10^{8}\right)\end{array}$} & \multicolumn{3}{|c|}{$\mathrm{DHL}\left(\times 10^{6}\right)$} \\
\hline & & & & Ec & $\mathrm{Pm}$ & $\mathrm{Kp}$ \\
\hline \multirow[t]{2}{*}{$\begin{array}{l}\mathrm{C} 3 \mathrm{H} / \\
\mathrm{HeN}\end{array}$} & $-{ }^{a}$ & $3.3 \pm 0.5$ & $6.6 \pm 0.5$ & $\begin{array}{l}0.9 \pm \\
0.3\end{array}$ & $\begin{array}{l}0.9 \pm \\
0.3\end{array}$ & $\begin{array}{l}0.5 \pm \\
0.2\end{array}$ \\
\hline & DSS & $2.3 \pm 0.7$ & $3.9 \pm 0.5^{\#}$ & $\begin{array}{l}5.1 \pm \\
2.0^{\#}\end{array}$ & $\begin{array}{l}2.8 \pm \\
0.6^{\#}\end{array}$ & $\begin{array}{l}14.0 \pm \\
2.5^{\#}\end{array}$ \\
\hline \multirow[t]{2}{*}{$\begin{array}{l}\mathrm{C} 3 \mathrm{H} / \\
\mathrm{HeJ}\end{array}$} & $-{ }^{a}$ & $1.0 \pm 0.4$ & $4.2 \pm 0.3$ & $\begin{array}{l}0.9 \pm \\
0.2\end{array}$ & $-b$ & $\begin{array}{l}5.0 \pm \\
0.9\end{array}$ \\
\hline & DSS & $1.6 \pm 0.5$ & $3.7 \pm 1.1^{\#}$ & $\begin{array}{l}4.7 \pm \\
0.6^{\#}\end{array}$ & $-b$ & $\begin{array}{l}9.2 \pm \\
0.9^{\#}\end{array}$ \\
\hline \multirow[t]{2}{*}{$\begin{array}{l}\mathrm{C} 3 \mathrm{H} / \\
\mathrm{HeN}\end{array}$} & $-{ }^{a}$ & $3.2 \pm 0.7$ & $5.9 \pm 1.1$ & $\begin{array}{l}0.3 \pm \\
0.04\end{array}$ & $\begin{array}{l}0.9 \\
0.1\end{array}$ & 0.70 .1 \\
\hline & TNBS & $1.9 \pm 0.8^{\#}$ & $0.5 \pm 0.1^{\#}$ & $\begin{array}{l}3.2 \pm \\
0.3^{\#}\end{array}$ & $\begin{array}{l}1.8 \pm \\
0.1^{\#}\end{array}$ & $\begin{array}{l}17.8 \pm \\
2.0^{\#}\end{array}$ \\
\hline \multirow[t]{2}{*}{$\begin{array}{l}\mathrm{C} 3 \mathrm{H} / \\
\mathrm{HeJ}\end{array}$} & $-{ }^{a}$ & $1.7 \pm 0.6$ & $20.9 \pm 2.1$ & $\begin{array}{l}3.5 \pm \\
0.6\end{array}$ & $-b$ & $\begin{array}{l}2.8 \pm \\
0.2\end{array}$ \\
\hline & TNBS & $0.6 \pm 0.1^{\#}$ & $7.0 \pm 0.8^{\#}$ & $\begin{array}{l}49.1 \pm \\
4.7^{\#}\end{array}$ & $-b$ & $\begin{array}{l}31.8 \pm \\
8.6^{\#}\end{array}$ \\
\hline
\end{tabular}

The test agents were orally administered for 3 days prior to TNBS treatment. The fresh feces was plated in $\mathrm{BL}, \mathrm{GAM}$, and $\mathrm{DHL}$ agar plates and cultured anaerobically (for BL and GAM agar plates) or aerobically (for DHL agar plates). The colonies grown in DHL agar media were selected and identified by $16 \mathrm{~S}$ rDNA analysis. Bifido, bifidobacteria; Ec, Escherichia coli; Pm, Proteus mirabilis; Kp, Klebsiella pneumonia.

a) Normal group treated with vehicle alone instead of colitic inducer.

b) Not detected.

All values are the mean \pm S.D. $(n=10)$. "Significantly different vs. normal group in each column of $\mathrm{C} 3 \mathrm{H} / \mathrm{HeN}$ or $\mathrm{C} 3 \mathrm{H} / \mathrm{HeJ}$ mice $(\mathrm{P}<0.05)$. 
B. animalis and B. cholerium grown in BL agar plates inhibited lipid peroxidation in liposomes prepared with L- $\alpha$-phosphatidylcholine, but E. coli, K pneumonia and $P$. mirabilis grown in DHL agar plates increased it (Fig. 4).

\section{Discussion}

IBD is a severe form of intestinal inflammation, the pathogenesis of which remains to be clearly understood. It is thought that the disease might be attributed to complex mucosal immune responses to resident enteric bacteria[30,31]. The innate immune system recognizes the presence of specific bacterial antigens through pattern recognition receptors $[7,8]$.

TLR-4 is an extensive family of pattern recognition receptors and compelling research has shown that LPS, which is expressed specifically by all gram-negative bacteria, binds to TLR-4 [32,33]. The triggering of TLR-4 complex signaling by LPS results in a cascade of events that leads to the secretion of proinflammatory mediators from monocytes and dendritic cells, which leads ultimately to the activation of an acquired immune response. Signaling through the TLR-4 complex contributes actively to the development of inflammation and may help to maintain an ongoing inflammatory response $[34,35]$. TLR-4 is potently expressed in intestinal epithelial cells from the colons of patients with IBD [6] and significantly up-regulated during DSS-induced colitis in mice [7].

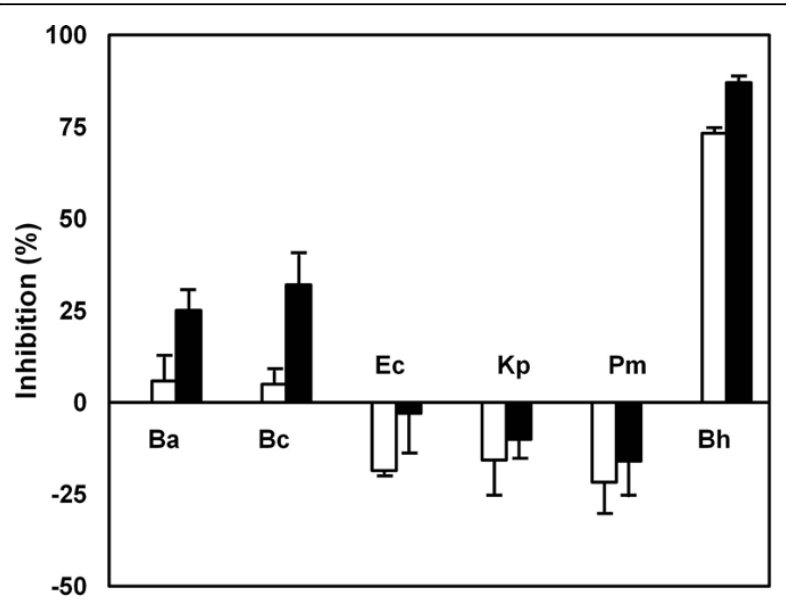

Figure 4 Intestinal bacteria increase lipid peroxidation in liposomes prepared with L- $\alpha$-phosphatidylcholine. Lipid peroxide in liposome was estimated by thiobarbituric acid-reactive substance assay. The intestinal bacteria previously cultured in GAM broth were collected by centrifugation (10,000 $\times \mathrm{g}$ for $30 \mathrm{~min})$ and washed twice with PBS. The resulting pellet was suspended in phosphate-buffered saline: Ba, Bifidobacterium animalis; $\mathrm{Bc}$, Bifidobacterium cholerium; Ec, Escherichia coli; Lp, Klebsiella pneumoniae; Pm, Proteus mirabilis. Bh indicates butylated hydroxylanisole. Test agents [20 (white bar), and $50 \mathrm{mg} / \mathrm{ml}$ (black bar)] was treated. All values are the mean \pm S.D. $(n=3)$.
In the present study, DSS and TNBS caused loss of body weight, and severe inflammation, manifested by shortened, thickened and erythematous colons in both $\mathrm{C} 3 \mathrm{H} / \mathrm{HeN}$ and $\mathrm{C} 3 \mathrm{H} / \mathrm{HeJ}$ mice. DSS and TNBS did not only potently activate $\mathrm{NF}-\kappa \mathrm{B}$, but also induced the expression of TLR-4 and proinflammatory cytokines IL$1 \beta$, TNF- $\alpha$ and IL- 6 in $\mathrm{C} 3 \mathrm{H} / \mathrm{HeN}$ mice, as previously reported [36,37]. However, DSS and TNBS-induced TNF- $\alpha$ and IL-1 $\beta$ expression less in $\mathrm{C} 3 \mathrm{H} / \mathrm{HeJ}$ mice than $\mathrm{C} 3 \mathrm{H} / \mathrm{HeN}$ mice, although NF- $\kappa \mathrm{B}$ activation was potently activated in both mice. DSS and TNBS caused more severe colonic inflammation and colon shortening in $\mathrm{C} 3 \mathrm{H} / \mathrm{HeN}$ mice than $\mathrm{C} 3 \mathrm{H} / \mathrm{HeJ}$ mice. Treatment with IL-1 $\beta$ in CaCo- 2 cells potently activated NF- $\kappa \mathrm{B}$, but did not induce TLR-4 expression. These results suggest that DSS and TNBS may induce colitis via the expression of IL- $1 \beta$, IL- 6 , and TNF- $\alpha$, and that IL- $1 \beta$ may be dependent on TLR-4-linked NF-kB activation.

Intestinal bacterial endotoxins, such as gram-negative lipopolysaccharides, activate TLR-4-linked NF-kB and cause colitic inflammation $[7,16,30]$. To confirm the role of intestinal bacteria in colitic inflammation, we measured colonic bacterial composition in DSS or TNBStreated mice. When $\mathrm{C} 3 \mathrm{H} / \mathrm{HeN}$ and $\mathrm{C} 3 \mathrm{H} / \mathrm{HeJ}$ mice were treated with DSS or TNBS, the number of anaerobes and bifidobacteria was significantly reduced, but the number of colonies grown in DHL medium, which is a selective medium for Enterobacteriaceae, was significantly increased. Proteus mirabilis, E. coli and K. pneumoniae were mainly detected in $\mathrm{C} 3 \mathrm{H} / \mathrm{HeN}$ mice, and $E$. coli and K. pneumoniae were detected in $\mathrm{C} 3 \mathrm{H} / \mathrm{HeJ}$ mice. These gram-negative bacteria, Proteus mirabilis, E. coli and $K$. pneumoniae, produces endotoxin, which activates TLR-4-linked NF-kB. Treatment with DSS or TNBS increased the number of gram-negative bacteria and decreased the number of bifidobacteria and anaerobes. DSS and TNBS caused more severe colitis in $\mathrm{C} 3 \mathrm{H} / \mathrm{HeN}$ mice than in $\mathrm{C} 3 \mathrm{H} / \mathrm{HeJ}$ mice, which paralleled changes in bacterial composition. Thus, treatment with DSS and TNBS may increase the growth of gram-negative bacteria, produce LPS, and cause colitis via TLR-4-linked NF-kB activation. However, DSS and TNBS caused colitis in $\mathrm{C} 3 \mathrm{H} / \mathrm{HeJ}$ mice, which is TLR-4-defective, as well as in $\mathrm{C} 3 \mathrm{H} / \mathrm{HeN}$ mice. These results suggest that DSS and TNBS may cause colitis via TLR-4-linked pathway as well as other pathway(s), such as oxidative stresses. Reactive oxygen species (ROS), such as peroxide anion, hydrogen peroxide, and hypochlorous acid, may actually be involved in the pathogenesis of IBD as treatment with superoxide dismutase significantly ameliorates the colitis [15]. DSS and TNBS increased malondialdehyde and 4-HNE in the colons of both mice, but reduced the glutathione content and superoxide dismutase and catalase activities, as previously reported [12-14]. 
Particularly, these colitic inducers dramatically increased 4- $\mathrm{HNE}$ levels in $\mathrm{C} 3 \mathrm{H} / \mathrm{HeN}$, compared with those in $\mathrm{C} 3 \mathrm{H} / \mathrm{HeJ}$. These results suggest that DSS and TNBS may cause colitis independently of TLR-4-linked NF- $\kappa$ B activation, and lipid peroxidation in colitis may be induced by TLR-4-linked NF- $\kappa$ B activation.

Enterobacteriaceae, E. coli, K. pneumoniae and P. mirabilis induced by the treatment with DSS or TNBS in mice increased lipid peroxidation in liposomes prepared by L- $\alpha$-phosphatidylcholine, but Bifidobacteria inhibited it. The results suggest that the colitic inducers, DSS and TNBS, may induce ROS directly as well as indirectly via the proliferation of Enterobacteriaceae. Based on these findings, DSS or TNBS may cause colitis by lipid peroxidation and enterobacterial proliferation, which may deteriorate the colitis by regulating proinflammatory cytokines via TLR-4-linked NF- $\kappa$ B activation pathway.

\section{Abbreviations}

(DSS): Dextran sulfate sodium; (TNBS): 2,4,6-trinitrobenzenesulfonic acid; (TLR4): Toll-like receptor 4; (LPS): Lipopolysaccharides; (4-HNE): 4-hydroxy-2nonenal; (TNF alpha): Tumor necrosis factor alpha; (IL-6): Interleukin-6; (ROS): Reactive oxygen species.

\section{Authors' contributions}

IA performed all of the experiments. EA performed the immunoassay into cell line. YJ performed the identification of intestinal bacteria. $\mathrm{DH}$ conceived of the study, and performed its design and coordination. All authors have read and approved the final manuscript.

\section{Competing interests}

The authors declare that they have no competing interests.

Received: 27 July 2009

Accepted: 1 February 2010 Published: 1 February 2010

\section{References}

1. Shanahan F: Crohn's disease. Lancet 2002, 359:62-69.

2. Binder V: Epidemiology of IBD during the twentieth century: an integrated view. Best Pract Res Clin Gastroenterol 2004, 18:463-479.

3. Rafii F, van Embdin R, van Lieshout LMC: Changes in bacterial enzymes and PCR profiles of fecal bacteria from a patient with ulcerative colitis before and after antimicrobial treatments. Dig Dis Sci 1999, 44:637-642.

4. Atreya R, Multer J, Fintoo S, Müllberg J, Jostock T, Wirtz S, Schütz M, Bartsch B, Holtmann M, Becker C, Strand D, Czaja J, Schlaak JF, Lehr HA, Autschbach F, Schürmann G, Nishimoto N, Yoshizaki K, Ito H, Kishimoto T, Galle PR, Rose-John S, Neurath MF: Blockade of interleukin 6 trans signaling suppresses T-cell resistance against apoptosis in chronic intestinal inflammation: evidence in crohn disease and experimental colitis in vivo. Nat Med 2000, 6:583-588.

5. Radema SA, Van Deventer SJ, Cerami A: Interleukin 1 beta is expressed predominantly by enterocytes in experimental colitis. Gastroenterology 1991, 100:1180-1186

6. Cario E, Podolsky DK: Differential alteration in intestinal epithelial cell expression of Toll-like receptor 3 (TLR3) and TLR-4 in inflammatory bowel disease. Infect Immun 2000, 68:7010-7017.

7. Ingalls RR, Heine $H$, Lien E, Yoshimura A, Golenbock D: Lipopolysaccharide recognition, CD14, and lipopolysaccharide receptors, Infect. Dis Clin North Am 1999, 13:341-353.

8. Chow JC, Young DW, Golenbock DT, Christ WJ, Gusovsky F: Toll-like receptor-4 mediates lipolysaccharide-induced signal transduction. J Biol Chem 1999, 274:10689-10692.

9. Poltorak A, He X, Smirnova I, Liu MY, Van Huffel C, Du X, Birdwell D, Alejos E, Silva M, Galanos C, Freudenberg M, Ricciardi-Castagnoli P,
Layton B, Beutler B: Defective LPS signaling in C3H/HeJ and C57BL/ 10ScCr mice: mutations in TLR-4 gene. Science 1998, 282:2085-2088.

10. Fukata M, Michelsen KS, Eri R, Thomas LS, Hu B, Lukasek K, Nast CC, Lechago J, Xu R, Naiki Y, Soliman A, Arditi M, Abreu MT: Toll-like receptor-4 is required for intestinal response to epithelial injury and limiting bacterial translocation in a murine model of acute colitis. Am J Physiol Gastrointest Liver Physiol 2005, 288:G1055-1065.

11. Mizoguchi A, Mizoguchi E: Inflammatory bowel disease, past, present and future: lessons from animal models. J Gastroenterol 2008, 43:1-17.

12. Kruidenier L, Kuiper I, Lamers CB, Verspaget HW: Intestinal oxidative damage in inflammatory bowel disease: semi-quantification, localization, and association with mucosal antioxidants. J Pathol 2003, 201:28-36.

13. Naito $Y$, Takagi $T$, Yoshikawa $T$ : Molecular fingerprints of neutrophildependent oxidative stress in inflammatory bowel disease. $J$ Gastroenterol 2007, 42:787-998.

14. Roessner A, Kuester D, Malfertheiner P, Schneider-Stock R: Oxidative stress in ulcerative colitis-associated carcinogenesis. Pathol Res Pract 2008, 204:511-524.

15. Han W, Mercenier A, Ait-Belgnaoui A, Pavan S, Lamine F, van Swam II, Kleerebezem M, Salvador-Cartier C, Hisbergues M, Bueno L, Theodorou V, Fioramonti J: Improvement of an experimental colitis in rats by lactic acid bacteria producing superoxide dismutase. Inflamm Bowel Dis 2006, 12:1044-1052.

16. Kim JS, Jobin C: The flavonoid luteolin prevents lipopolysaccharide induced NF-kB signaling and gene expression by blocking IkB kinase activity in intestinal epithelial cells and bone-marrow derived dendritic cells. Immunology 2005, 115:375-387.

17. Ito M, Ohishi K, Yoshida Y, Yokoi W, Sawada H: Antioxidative effects of lactic acid bacteria on the colonic mucosa of iron-overloaded mice. $J$ Agric Food Chem 2003, 51:4456-4460.

18. Qureshi ST, Lariviere L, Leveque G, Clermont S, Moore KJ, Gros P, Malo D: Endotoxin-tolerant mice have mutations in Toll-like receptor 4 (TLR-4). J Exp Med 1999, 189:615-625

19. Dieleman LA, Ridwan BU, Tennyson GS, Beagley KW, Bucy RP, Elson CO: Dextran sulfate sodium-induced colitis occurs in severe combined immunodeficient mice. Gastroenterology 1994, 107:1643-1652.

20. Neurath M, Fuss I, Strober W: TNBS-colitis. Int Rev Immunol 2000, 19:51-62.

21. Hollenbach E, Vieth M, Rosessner A, Neumann M, Malfertheiner $P$, Naumann M: Inhibition of RICK/Nuclear factor-kB and p38 signalling attenuates the inflammatory response in a murine model of Crohn Disease. J Biol Chem 2005, 280:14981-14988.

22. Mullane KM, Kraemer R, Smith B: Myeloperoxidase activity as a quantitative assessment of neutrophil infiltration into ischemic myocardium. J Pharmacol Methods 1985, 14:157-167.

23. Bradford MM: A rapid and sensitive method for the quantitation of microgram quantities of protein utilizing the principle of protein-dye binding. Anal Biochem 1976, 72:248-254.

24. Ohkawa H, Ohishi N, Yoke K: Assay of lipid peroxidases in animal tissue by thiobarbituric acid reaction. Anal Biol Chem 1978, 95:351-358.

25. Paglia DE, Valentine WN: Studies on the quantitative and qualitative characterization of erythrocyte glutathione peroxidases. J Lab Clin Med 1967, 701:158-169.

26. Prakash A, Medhi B, Avti PK, Saikia UN, Pandhi P, Khanduja KL: Effect of different doses of Manuka honey in experimentally induced inflammatory bowel disease in rats. Phytother Res 2008, 22:1511-1519.

27. Lee HS, Han SY, Bae EA, Huh CS, Ahn YT, Lee JH, Kim DH: Lactic acid bacteria inhibit proinflammatory cytokine expression and bacterial glycosaminoglycan degradation activity in dextran sulfate sodiuminduced colitic mice. Int Immunopharmacol 2008, 8:574-580.

28. Lee JH, Lee B, Lee HS, Bae EA, Lee H, Ahn YT, Lim KS, Huh CS, Kim DH: Lactobacillus suntoryeus inhibits pro-inflammatory cytokine expression and TLR-4-linked NF-kappaB activation in experimental colitis. Int J Colorectal Dis 2009, 24:231-237.

29. Hiraishi A: Direct automated sequencing of $16 \mathrm{~S}$ rDNA amplified by polymerase chain reaction from bacterial cultures without DNA purification. Lett Appl Micribiol 1992, 15:210-213.

30. Jung HC, Eckmann I, Yang SK, Panja A, Fierer J, Morzycka-Wroblewska E, Kagnoff MF: A distinct array of proinflammatory cytokine is expressed in human colon epithelia cells in response to bacterial invasion. J Clin Invest 1995, 95:55-65. 
31. Duchmann R, Kaiser I, Hermann E, Mayet W, Ewe K, Meyer zum Büschenfelde $\mathrm{KH}$ : Tolerance exists towards resident intestinal flora but is broken in active inflammatory bowel disease. Clin Exp Immunol 1995, 102:448-455.

32. Hoshimo K, Takeuchi O, Kawai T, Sanjo H, Ogawa T, Takeda Y, Takeda K, Akira S: Cutting edge: Toll-like receptor 4 (TLR-4)-deficient mice are hyporesponsive to lipopolysaccharide: evidence for TLR- 4 as the Lps gene product. J Immunol 1999, 162:3749-3752.

33. da Silva Correia J, Soldau K, Christen U, Tobias PS, Ulevitch RJ Lipopolysaccharide is in close proximity to each of the proteins in its membrane receptor complex transfer from CD14 to TLR-4 and MD-2. $J$ Biol Chem 2001, 276:21129-21135.

34. Takeda K, Kaisho T, Akira S: Toll-like receptors. Annu Rev Immunol 2003, 21:335-376.

35. O'Shea JJ, Murray PJ: Cytokine signaling modules in inflammatory responses. Immunity 2008, 28:477-487.

36. Zhang FX, Kirschning CJ, Macinelli R, Xu XP, Jin Y, Faure E, Mantovani A, Rothe M, Muzio M, Arditi M: Bacterial lipopolysaccharide activates nuclear factor-kappaB through interleukin-1 signaling mediators in cultured human dermal endothelial cells and mononuclear phagocytes. J Biol Chem 1999, 274:7611-7614.

37. Sands BE: Inflammatory bowel disease: past, present, and future. J Gastroenterol 2007, 42:16-25.

doi:10.1186/1476-9255-7-7

Cite this article as: Lee et al:: Dextran sulfate sodium and 2,4,6trinitrobenzene sulfonic acid induce lipid peroxidation by the proliferation of intestinal gram-negative bacteria in mice. Journal of Inflammation 2010 7:7.

\section{Submit your next manuscript to BioMed Central and take full advantage of:}

- Convenient online submission

- Thorough peer review

- No space constraints or color figure charges

- Immediate publication on acceptance

- Inclusion in PubMed, CAS, Scopus and Google Scholar

- Research which is freely available for redistribution

Submit your manuscript at www.biomedcentral.com/submit
C Biomed Central 